\title{
Why should we use atraumatic needles in lumbar puncture?
}

Por que usar agulhas atraumáticas em punção lombar?

Sandro Luiz de Andrade Matas

\begin{abstract}
Diagnostic lumbar puncture is essential to the diagnosis of central nervous system infections, subarachnoid haemorrhage and others neurological diseases. Myeloradicular involvement or life-threatening adverse events due to the procedure are rare, but less severe complications are more frequent. Post-lumbar puncture headache is the most common complication, by spinal fluid leakage due to delayed closure of a dural defect. Therefore, the development of fine needles, with differentiated atraumatic bevel, has contributed to minimize that problem. These generically called atraumatic needles cause less deformation of the dura mater then the Quincke ${ }^{\circledR}$ ones. So, why don't we use these atraumatic needles?
\end{abstract}

Keywords: lumbar puncture, complication, headache, meningitis, atraumatic needles.

\section{RESUMO}

A punção lombar é essencial para o diagnóstico de infecções do sistema nervoso central, hemorragia subaracnoídea e outras doenças neurológicas. O comprometimento mielorradicular ou efeitos adversos que envolvam risco de vida como consequência do procedimento são raros, mas complicações leves são mais frequentes. Cefaléia pós-punção lombar é a complicação mais comum, secundária a escoamento do líquido cefalorraquiano por fechamento tardio de uma lesão dural. Consequentemente, o desenvolvimento de agulhas finas, com bisel atraumático, tem contribuído para minimizar o problema. Estas agulhas, chamadas genericamente de atraumáticas, causam menos deformação da dura-mater que as agulhas tipo Quincke ${ }^{\circledR}$. Então, porque não usar estas agulhas atraumáticas?

Palavras-chave: punção lombar, complicação, cefaléia, meningite, agulhas atraumáticas.

The brain has two fluid compartments: interstitial and cerebrospinal fluid (CSF). Davson CSF system is called the "sink brain" because there is a slow flow of liquid from the parenchyma to the interstitial space and thence to the spinal fluid ${ }^{1}$. The presence of this liquid compartment has many advantages, first by supporting the growth of brain. The brain is less dense than water, and, despite having an average weight of $1,500 \mathrm{~kg}$, when suspended in CSF, weighs only $50 \mathrm{~g}$ floating in this liquid medium. Therefore, the CSF protects the brain against trauma mainly against the base of the skull. The CSF also regulates the pressure variations caused by intracranial expansive processes or venous obstruction, reducing the intracranial contents by flow through the foramen magnum, reflecting the Monro-Kellie-Burrows doctrine ${ }^{2,3}$, where the intracranial total volume is the sum of brain volume, the intracranial blood and CSF. As the intracranial volume is constant, any change in the brain parenchyma or blood volume is compensated by the decrease in the volume of $\mathrm{CSF}^{4}$. Another function is the removal of the products generated by brain metabolism. The brain is devoid of lymphatic vessels, then, such products fall in the interstitial and go directly into the venous system or to $\mathrm{CSF}^{2,5}$. The CSF also contributes to the distribution of biologically active substances through the brain, as in the hypothalamic-pituitary complex. The thyrotrophic-releasing and luteinizing hormone leave the hypothalamic secretory cells and go to CSF of the third ventricle. Fluctuation in these hormones in CSF brings physiological and behavioral changes in animals, making crystal this route of communication between regional structures of the brain through the spinal fluid. Similarly, electrolyte, CSF and osmolality changes modify the systemic controls, changing intake and excretion of liquids and other substances ${ }^{6}$.

CSF production is a specialized process performed mainly by the choroid plexus. Less than $10 \%$ of this production is extracoroidal, coming primarily from the interstitial fluid. The total volume of human's CSF ranges from 140 to $270 \mathrm{ml}$, $25 \%$ of which are within the ventricles and the subarachnoid space fills the remainder ${ }^{2}$. The CSF secretion is continuous 
and replaces the entire volume from 3 to 4 times in 24 hours at an approximate rate of $0.4 \mathrm{ml} / \mathrm{min}$, in which is an autonomously controlled production by peptidergic signals (vasoactive intestinal peptide and neuropeptide Y) and adrenergic ${ }^{1,6}$. The absorption of CSF is a continuous flow, without transport mechanisms, with an absorption corresponding to production. At the microscopic level, it's possible to see that the vacuoles are formed in the wall of the arachnoid villi unidirectionally to the venous sinuses. Therefore, despite the production of CSF held at a constant, absorption is made in dependence of CSF pressure and another factors ${ }^{5}$.

CSF is produced by the choroid plexus located within the cerebral ventricles (lateral, third and fourth ventricles). Soon after its formation, the CSF goes to subarachnoid space through the Luschka and Magendie foramina and reaches the brain and spinal cord surface. Therefore, any disease involving the central nervous system produces changes in the composition of the CSF, turning it into a sentinel diagnosis of neurological diseases. The ease of obtaining samples for analysis, through correct lumbar puncture, translates into powerful investigative tool in cases of infectious, neoplastic, autoimmune, neuropediatric, neurological and internal medicine in general. The collection of CSF is not always carried out by experts; it is a medical procedure, often in urgent situations where it's frequently made by the attending physicians ${ }^{7}$. This procedure can also be performed with diagnostic and therapeutic purposes, such as injection of radiopaque substances, radioactive substances, anesthetic proposed (spinal anesthesias), intrathecal chemotherapy treatments, for relief of intracranial hypertension, neurological disorders, among other conditions ${ }^{6}$.

\section{Complications related to CSF collection}

Some complications may occur subsequent to the puncture, such as, post-puncture headache (PDPH), back pain, bleeding and bruising at the puncture site, tinnitus and hearing loss, paresis of the sixth nerve (unilateral or bilateral), subdural hematoma, post puncture meningitis, arachnoiditis following puncture and, more rarely, brain herniation and death ${ }^{8-13}$. There are rare reports of death after lumbar puncture. When it occurs, it's believed that it may have been caused by, used as an example, bacterial meningitis or cerebral hemorrhage ${ }^{14}$.

The most common complication that deserves our focus is the post-puncture headache. The father of spinal anesthesia, Dr. August Bier, was the first to report this frequent complication for over 100 years. According to the International Classification of Headache in International Classification of Headache Disorders - ICHD-II ${ }^{15}$, post-puncture headache is an iatrogenic orthostatic headache condition caused by low pressure within the cerebrospinal system.

Several theories exist to explain the genesis of headache, however two theories prevail. One of them is that the headache was due to reflex vasodilation that occur in response to hypotension CSF space. The other theory is based on the traction of intracranial structures, which are innervated for pain, caused by brain accommodation in the upright position due to low CSF pressure. In this case, the traction of the nerve roots $\mathrm{C} 1$ to $\mathrm{C} 3,5$ th, 10 th and 11 th nerves originate neuralgic syndrome $e^{2,8,11,16}$.

The risk of development of headache depends on a number of factors and the incidence varies depending on the population studied, the puncture techniques and types of used needles, among others. The needle gauge and tip shape are the main factors involved in the genesis of this symptom. The frequency of PDPH appears to be doubled in the diagnostic punctures in relation to the anesthetics, in which are used thinner needles and atraumatic tip ${ }^{17}$. Evans ${ }^{18}$, in a review of the literature between 1966 and 2000, carried out for the therapeutics and technology assessment Subcommittee of the American Academy of Neurology, observed an incidence of $20 \%$ to $40 \%$ of PDPH, in which gauge needles 20:22 were used. On the other hand, Strupp ${ }^{19}$ found that $12 \%$ of patients using $22 \mathrm{G}$ atraumatic needle had headache, compared with $24 \%$ of patients punctured with needles $22 \mathrm{G}$ traumatic. In a systematic review of the literature, which was carried out by Williams and colleagues ${ }^{13}$, prospective studies were found comparing the same caliber needles (22G) in relation to traumatic and atraumatic tip. They observed that the development of PDPH in the group of traumatic needles was significantly higher (36\% versus $3 \%, \mathrm{P}=0.002)$. Similar results were found in other studies, but they hadn't been studied in smaller needles sizes. It's based on the conception that it would not be appropriate for diagnosis in neurology for having very slow flow, preventing the correct pressure measurement. However, atraumatic and very thin needles in inexperienced hands could determine various unsuccessful attempts to puncture. This fact occurs by small caliber needle associated with the slow flow of CSF, making it seems that the puncture resulted in failure. Much has been said regarding the care to observe the orientation of the needle bevel during the puncture. However, a neuroanatomical revision of microscopic dural structure carried out by Reina and colleagues ${ }^{20,21}$, revealed that there is no longitudinal pattern of collagen and elastic fibers. However, the non-traumatic lacerations caused by the needles in both the dura and arachnoid are smaller than those caused by the needles with a bevel cutting, as the Quincke ${ }^{\circledR}$.

There are other factors that influence the occurence of PDPH. Pregnant women are more likely to have the symptom, especially during childbirth. On these occasions the lumbar puncture is performed in the sitting position and the patient performs strong abdominal press, the expulsive phase of labor. This fact provides a great increase on the CSF pressure and consequently the fluid is drained to the spinal epidural space, where the pressure is usually zero 
or negative ${ }^{17}$. Majd and colleagues ${ }^{22}$, in a study conducted in Iran, questioned whether the position of the patient during collection could influence the onset of PDPH. They concluded that the sitting position influences significantly in contrast to the lateral decubitus position. However, the work does not seem to have been well conducted because they have used Quincke needles ${ }^{\circledR}$ caliber $21 \mathrm{G}$. The incidence of PDPH is higher in the range 18-30 years of age, in tall and thin women and in patients with a prior history of chronic headache, although there is no relationship between migraine and PDPH. Unlike this group, patients under 13 years of age, with more than 60 years and obese appear to be protected in this syndrome ${ }^{8}$.

In order to prevent $\mathrm{PDPH}$, the patients are instructed to stay at rest lying down for 24 hours after the lumbar puncture, regardless of the caliber or type of needle used. It's recommended not vigorous oral hydration at the rest period ( 1 to 2 liters of fluid per 24 hours). After this period, patients are allowed to get up, but they should not perform exaggerated physical activities (sports practice), only the activities of daily living ${ }^{13,16,23,24}$. Such measure is shared by many specialized laboratories, although with no experimental support $^{13}$. Another prophylactic measure advocates taking care with the needle bevel during the lumbar puncture. The orientation of the needle bevel must be longitudinally disposed to the meninges fibers, and do not remove the needle from the patient without resetting the needle's chuck. Although there are randomized clinical trials confirming that this approach is beneficial, there is no logical explanation for these advices, since the dural ultra-structures have random distribution of its collagen and elastic fibers ${ }^{21,25}$. Replacement chuck removes arachnoid bending or roots from inside the needle. Another pertinent reason would be to avoid leaving the chuck without the proper destination by forgetfulness, preventing the risk of accidents ${ }^{16}$.

Therefore, taking into consideration the various clinical trials already conducted, there seems to be no doubt regarding the use of atraumatic needles compared to the sharp ones $^{26-30}$. Its widespread use is restricted only by the high cost of these needles. Tung and colleagues studied the cost-benefit of using these needles on diagnostic units in the United States of America. They observed that the overhead of the patient with PDPH far outweighs the cost of these needles in routine diagnosis justifying their use $\mathrm{e}^{30}$.

Typically, the symptoms appear on average 24 to 48 hours after the puncture and can last for days or for a few weeks. The location of the pain may be frontal, frontotemporal or occipital, and is much worse with ambulation and disappears at bedtime. During the symptoms, may occur nausea, vomiting, tinnitus, hearing loss, meningeal signs, nuchal rigidity, photophobia, and diplopia. The diplopia can occur from 4 to 10 days after the puncture, usually in the absence of headache, affecting the diagnosis. Such complication subsides from 2 weeks to 8 months $^{8}$. The headache is incapacitating and extremely unpleasant, causing the patient an often demand to the emergency room. Sometimes the physician suspicion is post puncture meningitis and requests reexamination, with another lumbar puncture, worsening the patient's situation. Therefore, when the PDPH arises, is important to diagnose it and start the treatment, which can be divided into two stages: conservative (with directions, drugs and hydration) and invasive (known as "blood patch"). After started the $\mathrm{PDPH}$, conservative treatment is based on pain sedation and control of neurovegetative symptoms. The drugs used are non-hormonal anti-inflammatory drugs and analgesics associated with caffeine ${ }^{18}$, with recommendation to stay at rest in bed for 48 hours, if possible, in the Trendelemburg position. In emergency services, in which are used large gauge needles, some cases of PDPH are refractory to conservative treatment, requiring invasive treatment. In these cases, conducting blood patch is necessary, and when performed by an experienced professional is highly effective solving the problem. The method consists of puncturing the same place where first puncture was performed, which resulted in the PDPH, with Tuohy epidural needle type or similar, reaching the epidural space. At this moment, is collected from 20 to $40 \mathrm{ml}$ of patient's blood and injected into the epidural space, in attempt to seal the CSF leak that was done there. As we can see, is a delicate procedure that should be performed by experienced professionals ${ }^{31}$. Complications of this procedure are lumbar and nuchal pain, infection (epidural abscess and empyema), arachnoiditis and incidental puncture of the subarachnoid spaces and the injection of blood into the space ${ }^{16}$.

\section{References}

1. Irani DN. Cerebrospinal fluid in clinical practice: Elsevier Health Sciences; 2008.

2. Fishman RA. Cerebrospinal fluid in diseases of the nervous system: Saunders Philadelphia; 1992.

3. Morrison LM, McCrae AF, Foo I, Scott DB, Wildsmith JA. An in vitro comparison of fluid leakage after dural puncture with Atraucan, Sprotte, Whitacre, and Quincke needles. Regl Anesth 1996;21:139-143.
Weil A, Zeiss F, Cleveland D. The determination of the amount of blood in the central nervous system after injection of hypertonic solutions. Am J Physiol--Legacy Content 1931;98:363-367.

5. Koh L, Zakharov A, Johnston M. Integration of the subarachnoid space and lymphatics: is it time to embrace a new concept of cerebrospinal fluid absorption. Cerebrospinal Fluid Res 2005;2:6.

6. Johanson CE, Duncan 3rd J, Klinge PM, Brinker T, Stopa EG, Silverberg 
GD. Multiplicity of cerebrospinal fluid functions: New challenges in health and disease. Cerebrospinal Fluid Res 2008;5:441-450.

7. Straus SE, Thorpe KE, Holroyd-Leduc J. How do I perform a lumbar puncture and analyze the results to diagnose bacterial meningitis? JAMA 2006;296:2012-2022.

8. Alstadhaug K, Odeh F, Baloch F, Berg D, Salvesen R. Post-lumbar puncture headache. Tidsskrift for den Norske lægeforening: tidsskrift for praktisk medicin, ny række 2012;132:818.

9. Arcand G, Girard F, McCormack M, Chouinard P, Boudreault D, Williams S. Bilateral sixth cranial nerve palsy after unintentional dural puncture. Canad J Anesth 2004;51:821-823.

10. Cherng Y-G, Chen I-Y, Liu F-L, Wang M-H. Paraplegia following spinal anesthesia in a patient with an undiagnosed metastatic spinal tumor. Acta Anaesth Taiwanica 2008;46:86-90.

11. Ghaleb A. Postdural puncture headache. Anesth Res Practice 2010; 2010:1-6.

12. Moradi M, Shami S, Farhadifar F, Nesseri K. Cerebral subdural hematoma following spinal anesthesia: report of two cases. Case Reports Med 2012;2012:1-4.

13. Williams J, Lye D, Umapathi T. Diagnostic lumbar puncture: minimizing complications. Intern Med J 2008;38:587-591.

14. Oliver WJ, Shope TC, Kuhns LR. Fatal lumbar puncture: fact versus fiction-an approach to a clinical dilemma. Pediatrics 2003;112: 174-176.

15. Olesen J, Steiner T. The International classification of headache disorders, 2nd edn (ICDH-II). J Neurol, Neurosurg Psychiatr 2004;75:808-811.

16. Sempere A, Berenguer-Ruiz L, Lezcano-Rodas M, Mira-Berenguer F, Waez M. Punción lumbar: indicaciones, contraindicaciones, complicaciones y técnica de realización. Revista de neurología 2007; 45:433-436.

17. Bradbury C, Singh S, Badder S, Wakely L, Jones P. Prevention of postdural puncture headache in parturients: a systematic review and meta-analysis. Acta Anaesthesiol Scand 2013;57:417-430.

18. Evans RW, Armon C, Frohman EM, Goodin DS. Assessment: prevention of post-lumbar puncture headaches report of the therapeutics and technology assessment subcommittee of the American Academy of Neurology. Neurology 2000;55:909-914.

19. Strupp M, Schueler O, Straube A, Von Stuckrad-Barre S, Brandt T.
"Atraumatic" Sprotte needle reduces the incidence of post-lumbar puncture headaches. Neurology 2001;57:2310-2312.

20. Reina MA, de Leon-Casasola OA, Lopez A, De Andres J, Martin S, Mora M. An in vitro study of dural lesions produced by 25-gauge Quincke and Whitacre needles evaluated by scanning electron microscopy. Reg Anesth Pain Med 2000;25:393-402.

21. Reina MA, López A, Machés F, de Leon Casasola O, De Andrés JA. Electron microscopy and the expansion of regional anesthesia knowledge. Tech Reg Anesth Pain Manag 2002;6:165-171.

22. Majd SA, Pourfarzam S, Ghasemi H, Yarmohammadi ME, Davati A, Jaberian M. Evaluation of pre lumbar puncture position on post lumbar puncture headache. J Res Med Sci 2011;16:282.

23. Sudlow C, Warlow C. Posture and fluids for preventing post-dural puncture headache. Cochrane Database of Systematic Reviews. $2001 ; 2$.

24. Teunissen C, Petzold A, Bennett J, et al. A consensus protocol for the standardization of cerebrospinal fluid collection and biobanking. Neurology 2009;73:1914-1922.

25. Reina MA, Lopez-Garcia A, de Andres-Ibanez JA, et al. Electron microscopy of the lesions produced in the human dura mater by Quincke beveled and Whitacre needles. Rev Esp Anestes Reanimacion 1997;44:56-61.

26. Carson D, Serpell M. Choosing the best needle for diagnostic lumbar puncture. Neurology 1996;47:33-37.

27. Demaerschalk B, Wingerchuk D, editors. Atraumatic dural puncture needles for preventing postdural puncture headache: meta-analysis of randomized controlled trials. Neurology: Lippincott Williams \& Wilkins 530 Walnut St, Philadelphia, USA; 2002.

28. Lavi R, Yernitzky D, Rowe J, Weissman A, Segal D, Avivi I. Standard vs atraumatic Whitacre needle for diagnostic lumbar puncture: a randomized trial. Neurology 2006;67:1492-1494.

29. Luostarinen L, Heinonen T, Luostarinen M, Salmivaara A. Diagnostic lumbar puncture. Comparative study between 22-gauge pencil point and sharp bevel needle.J Headache Pain 2005;6:400-404.

30. Tung CE,SoYT, Lansberg MG. Cost comparison between the atraumatic and cutting lumbar puncture needles. Neurology 2012;78:109-113.

31. Desai MJ, Dave AP, Martin MB. Delayed radicular pain following two large volume epidural blood patches for post-lumbar puncture headache: a case report. Pain physician 2010;13:257. 